\title{
MtDNA barcode identification of fish larvae in the southern Great Barrier Reef, Australia
}

\author{
GRAHAM G. PEGG, BILLY SINCLAIR, LEICA BRISKEY and WILLIAM J. ASPDEN. \\ Marine Molecular Genetics and Biotechnology Group, Central Queensland University, Rockhampton, \\ Queensland, Australia. E-mail: g.pegg@cqu.edu.au
}

\begin{abstract}
SUMMARY: Planktonic larvae were captured above a shallow coral reef study site on the Great Barrier Reef (GBR) around spring-summer new moon periods (October-February) using light trap or net capture devices. Larvae were identified to the genus or species level by comparison with a phylogenetic tree of tropical marine fish species using mtDNA HVRI sequence data. Further analysis showed that within-species HVRl sequence variation was typically 1-3\%, whereas between-species variation for the same genus ranged up to $50 \%$, supporting the suitability of $H V R I$ for species identification. Given the current worldwide interest in DNA barcoding and species identification using an alternative mtDNA gene marker (coxl), we also explored the efficacy of different primer sets for amplification of coxI in reef fish, and its suitability for species identification. Of those tested, the Fish-F1 and -R1 primer set recently reported by Ward et al. (2005) gave the best results.
\end{abstract}

Keywords: reef fish, mtDNA, HVR1, cox1, DNA barcoding, species identification.

RESUMEN: IDENTIFICACIÓN DE LAS LARVAS DE PECES MEDIANTE MTDNA EN LA PARTE SUR DE LA GRAN BARRERA DE CORAL, AUSTRALIA. - Las larvas estudiadas fueron capturadas en el plancton de una zona coralina somera en la Gran Barrera de Coral en períodos de luna-nueva de la estación primavera-verano (octubre-febrero). Su captura se realizó mediante trampas de luz o redes de plancton. Las larvas fueron identificadas a nivel de género o especie por la comparación de un árbol filogenético de especies de peces tropicales marinas usando datos de la secuencia HVR1 del DNA mitocondrial. El análisis adicional demostró que, para una misma especie, la variación de la secuencia HVR1 era típicamente 1-3\%, mientras que entre especies del mismo género la variación fue de hasta 50\%, apoyando la conveniencia del uso del HVR1 para la identificación a nivel específico. Dado el interés mundial actual en el "código de barras genético" y en la identificación de especies usando otro marcador genético de DNA mitochondrial, el coxl, se exploró también la eficacia de diversos "primers" para la amplificación del coxl en peces de los arrecifes, y su conveniencia para la identificación específica. De los "primers" probados, el Fish-F1 y el -R1 set recientemente reportado por Ward et al. (2005) dieron los mejores resultados.

Palabras clave: peces de coral, mtDNA, HVR1, cox1, DNA identificación específica por código de barras genético.

\section{INTRODUCTION}

Australia's Great Barrier Reef (GBR) is recognised internationally for its importance as a tropical marine fish and coral reef biodiversity reserve, with up to 30 percent of the total reef area now protected as 'Green Zones'. In 2004, new fisheries rules in the State of Queensland were introduced to prohibit the taking of all regulated reef fish for nine-day closure periods around the new moon in the spring/early summer months (October-December) as a further measure to improve the chances of successful spawning of Lutjanus, Lethrinus, Plectropomus and other reef fish species important to the commercial and recreational fishery.

The current study was undertaken at an inshore shallow reef in the southern GBR (approximate latitude of 23 degrees south of the equator), where surface water temperature ranges from 18 degrees in winter to 28 degrees in summer. Larvae were cap- 
tured around the new moon periods in spring 2004 by light traps and by plankton nets. Because identification of freshly hatched fish larvae to species level is often difficult due to poorly defined morphological characteristics (Leis and Carson-Ewart, 2004), we were interested in investigating DNA analysis methods that would enable unequivocal identification of larval fish or planktonic eggs. Two distinct approaches were to be explored, both of which involved mitochondrial (mtDNA) sequencing. Our group had been using mtDNA $H V R I(D-$ loop) non-coding sequence to study within-species population diversity for adult reef fish (Aspden et $a l ., 2005$ ) and in this study we sought to compare the suitability of HVRI sequence data compared with Cytochrome Oxidase subunit 1 ( $\operatorname{cox} l$ ) sequence data for species identification of larvae. The expectation was that lesser within-species variation would be expected for the functional coxl gene sequences (approximately $650 \mathrm{bp}$.), whereas more genetic diversity might be expected for the non-coding HVRI gene. The hypothesis to be tested in the study was whether coxl sequence data were sufficiently divergent between closely related species to enable unambiguous identification, or whether HVRI sequence data gave too much variation to be useful as a specific species identifier. We also wished to test a number of the coxl primer sets for fish reported in the literature to determine which primers gave the best results for reef fish. The study was timely, since Hebert et al. (2003) had initiated an international Barcode of Life project proposing that the coxl gene sequence could be used to differentiate between most animal species, including fishes. Subsequent to initiating this study, examples of the application of the barcoding concept to adult and larval fish identification have been reported by Ward et al. (2005) and Steinke et al. (2005).

\section{MATERIALS AND METHODS}

\section{Larvae capture}

Larvae were captured using a combination of light traps and plankton net devices. The light traps $(900 \times 300 \times 300 \mathrm{~mm})$ were constructed from translucent plastic boxes held together by cable ties. A waterproof pond light $(50 \mathrm{~W})$ was fixed into the base of the trap along with a 500 litre per hour electric bilge pump (Rule Corp, USA), thereby facilitat- ing passage of larvae (and eggs) through a grid into the lower section of the trap. The light and pump were powered by a $12 \mathrm{~V}$ battery and the trap was suspended vertically 1 metre below the surface beside the research vessel for 2-hour periods. At other times, small zooplankton nets $(50 \mathrm{~cm}$ diameter), sometimes incorporating a $10 \mathrm{~W}$ light, were let out into the $4 \mathrm{~km} / \mathrm{h}$ tidal current to $0-1 \mathrm{~m}$ depth. A dual bongo plankton net of $70 \mathrm{~cm}$ diameter (Ocean Instruments, USA) was towed obliquely at a constant speed of 2 knots from a depth of 15 metres to the surface over 10 minutes. Captured larvae and eggs were stored in $80 \%$ ethanol / distilled water at $0^{\circ} \mathrm{C}$ in the field and later sorted with the aid of microscopy. Captures of individual fish larvae types ranged from a single specimen to many hundreds. Typically, groups ( $n=5$ to 20 or more) of the same species were captured within any collection interval within the sampling period.

\section{Adult fish capture}

Representative juvenile and adult fish of known species for this study were caught by line fishing as approved by Queensland Fisheries Regulations. Small pectoral fin clip samples were stored initially in $20 \%$ DMSO / saturated brine solution at room temperature, and later washed and transferred into $80 \%$ ethanol solution and refrigerated. The field work was sanctioned by Marine Parks Permit G04/12132.1 and CQU Animal Ethics Permit A04/06-160.

\section{DNA sequencing}

Total DNA was extracted from larval and adult fish tissue using a standard proteinase $\mathrm{K}, \mathrm{NaCl} / \mathrm{chlo-}$ roform method (Sambrook et al., 1989). The coxl gene (approximately $650 \mathrm{bp}$ in length) located in the mitochondrial genome was amplified using three sets of primers synthesised by Geneworks, Adelaide: FishF1-5'TCAACCAACCACAAAGACATTGGCAC3', FishR1-5'TAGACTTCTGGGTGGCCAAAGAATCA3' (Ward et al., 2005); cichlidBS 1(F)-5' GGTCAACAAATCATAAAGATATTGG3', cichlidBS2(R)-5'TAAACTTCAGGTGACCAAAAAATCA3' (Sparks, 2003 ); and tautog-BS1(F) 5'AGTATAAGCGTCTGGGTAGTC3' tautog-BS2(R)- 5'CCTGCAGGAGGAGGAGAYCC3' (Orbacz and Gaffney, 2000). PCR of the $H V R I$ genetic sequence utilised universal primers 
L15995 and H16498, previously reported to generate the HVRl fragment in parrot fish (Bay et al., 2004).

The coxl and HVRl fragments were amplified as follows. Each PCR reaction mix totalled $25 \mu \mathrm{l}$ and included $100 \mu \mathrm{M}$ dNTP, 7.5 pmol of each primer, 1 $\mathrm{mM} \mathrm{MgCl} 2,2.5 \mu 1$ 10X Buffer (Promega), 1.0 unit Taq polymerase (Promega), $17.8 \mu 1$ sterile MQ water and $1 \mu \mathrm{l}$ of DNA template (ca. $25 \mathrm{ng}$ ). Either a Perkin Elmer GeneAmp PCR System 2400, a BIO-RAD iCycler, or a BIO-RAD Mycylcer thermal cycler was used. Standard PCR conditions varied slightly for the 3 sets of coxl primers tested in this study. For the tautog and cichlid primers the thermal cycle regime consisted of: $5 \mathrm{~min}$ at $95^{\circ} \mathrm{C}$ for 1 cycle; $1 \mathrm{~min}$ at $95^{\circ} \mathrm{C}, 1 \mathrm{~min}$ at $47^{\circ} \mathrm{C}$, and $1 \mathrm{~min}$ at $72^{\circ} \mathrm{C}$ for 35 cycles; and $5 \mathrm{~min}$ at $72^{\circ} \mathrm{C}$ for 1 cycle. Samples were then held at $4^{\circ} \mathrm{C}$ until retrieved. The thermal cycle for the Fish-1F and $\mathrm{R} 1$ primers consisted of: $2 \mathrm{~min}$ at $95^{\circ} \mathrm{C}$ for 1 cycle; $30 \mathrm{~s}$ at $94^{\circ} \mathrm{C}$, $30 \mathrm{~s}$ at $54^{\circ} \mathrm{C}$, and $1 \mathrm{~min}$ at $72^{\circ} \mathrm{C}$ for 35 cycles; and $10 \mathrm{~min}$ at $72^{\circ} \mathrm{C}$. Samples were then held at $4^{\circ} \mathrm{C}$ on the thermocycler until collection. For HVRI amplification, Touchdown PCR was used. The protocol involved an initial $2 \mathrm{~min}$ at $94^{\circ} \mathrm{C}$ followed by 5 cycles of $30 \mathrm{~s}$ at $94^{\circ} \mathrm{C}, 30 \mathrm{~s}$ at $45^{\circ} \mathrm{C}$ and $2 \mathrm{~min}$ at $72^{\circ} \mathrm{C}$, then 5 cycles with annealing temperature reduced to $43^{\circ} \mathrm{C}$, then 25 cycles with annealing temperature reduced to $41^{\circ} \mathrm{C}$, followed finally by 10 min at $72^{\circ} \mathrm{C}$.

The amplified products and size standards were run on a $1 \%$ agarose gel stained with Sybr Green (Astral). The gels were visualised and photographed using a BIO-RAD Gel Documentation Camera. Bands (ca. $400 \mathrm{bp}$ for HVRl and ca. $650 \mathrm{bp}$. for coxl) were excised from the gels and placed into separate Eppendorf tubes. The Promega Wizard SV PCR and Gel Cleanup System was used to extract the DNA from the gel. The amplified products were then sequenced using the BigDye ${ }^{\circledR}$ Terminator v3.1 Cycle sequencing kit (Applied Biosystems, Inc) following the thermocycler protocol listed by Applied Biosystems and sequenced both in the forward and reverse directions using an ABI Prism 310 genetic analyser or an AB 3130 Genetic Analyser.

\section{Data analysis}

For the major Lethrinus and Lutjanus species, 20-30 individual fish samples were sequenced. For larvae that were single or few samples, the sequenc- ing was done in both the forward and reverse directions and the sequences were then checked manually to see that the sequence information was entirely consistent from both directions. Any doubtful base calls were checked manually. If necessary, the sequencing run or the entire DNA extraction/amplification/sequencing reaction was repeated to resolve any doubtful data.

Sequences were aligned using Chromas v1.45 (Technelysium Pty. Ltd., Australia) and BioEdit v7.0.4.1 (Ibis Therapeutics, CA., USA) freeware. Genetic distances (corrected) were calculated using the Tamura-Nei model within MEGA v3.1 (Kumar et al., 2004). Phylogenetic trees were calculated using the Neighbour Joining procedure of MEGA v3.1, the model being number of differences and complete deletion for gaps and missing data. The following MtDNA HVRI sequences (species, accession number) were accessed from GenBank: Chlorurus sordidus, AY392743; Lutjanus erythropterus, AY664534; Pristopomoides multidens, AF192863; Siganus vulpinus, AY057327; Atherinomorus ogilbyi, AY026097; Siganus doliatus, AY057325; Engraulis japonicus, DQ219881.

\section{RESULTS}

\section{Within species genetic variation of $H V R I$}

Figure 1 shows typical 1-3\% within-species variation for mtDNA HVRl sequences (approximately $420 \mathrm{bp}$ ) for reef snapper species Lethrinus miniatus and Lethrinus laticaudis, and for red emperor (Lutjanus sebae) for groups of fish from the same reef location $(\mathrm{n}=15-25)$.

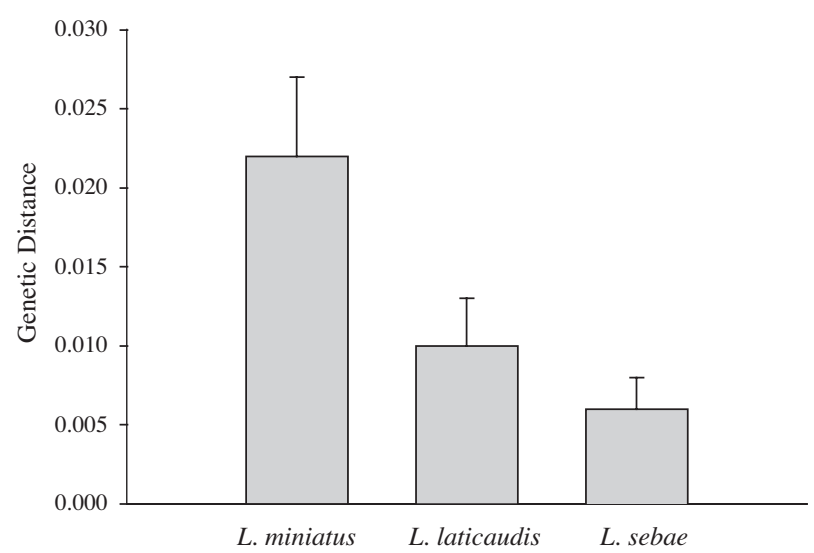

FIG. 1. - Within-species variation for mtDNA HVRl sequences for some commercial reef fish species calculated using MEGA v3.1 with Tamura-Nei model ( $n=15-25$ for each group; Means + SEM). 
TABLE 1. - Between-species HVR1 mean genetic distances for example reef snapper species calculated using MEGA v3.1 with Tamura-Nei model.

\begin{tabular}{lccc}
\hline & $\begin{array}{c}\text { Lethrinus } \\
\text { laticaudis }\end{array}$ & $\begin{array}{c}\text { Lethrinus } \\
\text { miniatus }\end{array}$ & $\begin{array}{c}\text { Lutjanus } \\
\text { sebae }\end{array}$ \\
\hline Lethrinus miniatus & 0.31 & & \\
Lutjanus sebae & 0.47 & 0.50 & 0.17 \\
Lutjanus adetii & 0.46 & 0.48 & 0.17 \\
\hline
\end{tabular}

\section{Between species genetic variation of $H V R I$}

A matrix of the between species mtDNA HVRI genetic distances for commercially important reef snapper species L. laticaudis, L. miniatus and L. sebae is shown in Table 1. The data shows between-species HVRl sequence differences ranging from 17 to $50 \%$ among these three species, demonstrating the potential utility of $H V R I$ sequences for species specific markers.

\section{Primer selectivity for marine fish coxl sequences}

All three primer sets tested for coxl amplification yielded amplicons having sizes of approximately $650 \mathrm{bp}$ and for which BLAST analysis using GenBank gave partial matches for fish species cytochrome oxidase, or portions of total mitochondrial DNA gene sequences. However, the FishF1 and R1 primer set for coxl (Ward et al., 2005) consistently gave amplicons which yielded longer length and cleaner sequence data than with either of the other two primer sets tested. The amplicons generated from the same DNA sample for Lutjanus sebae with FishF1/R1 and tautog-BS1 (F/R) showed only $50 \%$ sequence similarity when analysed using Chromas v1.45 and BioEdit v7.0.4.1. As discussed by Ward et al. (2005), researchers need to be mindful of pseudo-gene amplification and the tautog primers used might have initiated amplification of shorter nuclear DNA sequences originating from mitochondrial DNA (NUMTs), as discussed by Zhang and Hewitt (1996) and Richly and Lester (2004), or they might have amplified other mitochondrial DNA besides coxl.

\section{Species discrimination using cox 1 sequence comparisons}

Nearest neighbour analyses of the coxl sequences generated in this study were conducted with the bar- code of life fish ID database for Australian fishes (available at www.barcodinglife.org), yielding either identification for fish species coxl sequences already in the database, or logical closest related species in all cases. This analysis and the recent report by Ward et al. (2005) strongly support the contention that coxl sequences are highly useful for identification of marine fish species.

\section{DISCUSSION}

The question of fish and fish egg identification using DNA analysis methods is being pursued by many laboratories around the world. The use of modern molecular genetics techniques combined with taxonomic expertise provides a very powerful approach to solving existing taxonomic dilemmas, and allows new insights into the relatedness and evolution of fish species.

In a recent study (Aspden et al., 2005), our group utilised HVRl sequences to study the population differences for red throat emperor Lethrinus miniatus across its distribution along the East and West Australian coasts. In the present study we compared the within species HVRI sequence variation for two other commercial reef fish species (Lethrinus laticaudis and Lutjanus sebae) compared with L. miniatus (Fig. 1). With only 1-3\% variation within species, but up to $50 \%$ difference between species (Table 1), it therefore seemed feasible to explore using $H V R I$ sequences to develop a putative taxonomic identification tree for reef fish species. An example partial tree construct using neighbour joining analysis for fish HVRI sequences is shown in Figure 2. Fish from the same genus (see the Lethrinid and Lutjanid examples shown) all align closely, suggesting that though HVRl is a non-coding genetic sequence, this gene marker is remarkably useful for distinguishing between closely related species. Some of the larvae accessions from the 2004 collection for this study are also shown in Figure 2 and are indicated with an L prefix. As examples, L04 and L11 were closely aligned to Engraulis japonicus and are proposed to be the Australian anchovy Engraulis australis. The analysis suggests that L09 is a Lethrinus species, most likely a larval form of the spangled emperor Lethrinus nebulosus, while L03, L08, L13 and L24 are Siganus species. Tropical pelagic species such as hardy 


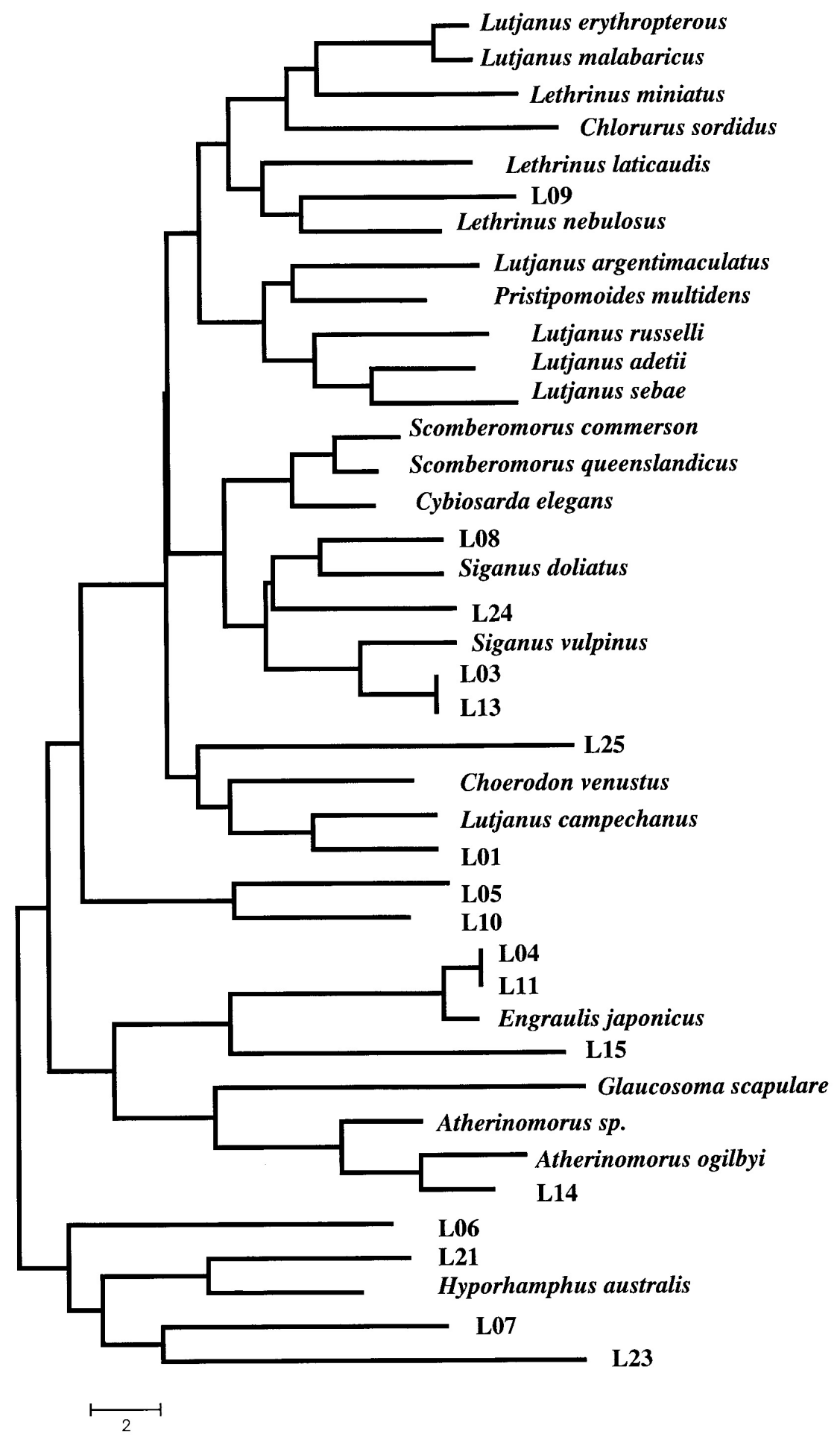

FIG. 2. - NJ topology of larvae by MtDNA HVR1 sequence comparisons calculated using MEGA v3.1.

heads Atherinomorus (L14) are also readily identified by $H V R I$ sequence comparisons.

While encouraged by these preliminary data proving the usefulness of $H V R 1$ sequence comparisons for species identification, the international Barcode of Life project initiated by Hebert et al.
(2003) suggested that another mitochondrial gene sequence, namely cytochrome oxidase subunit 1 ( $\operatorname{cox} 1)$, be used as the gene marker of choice for species discrimination. As it is a structural gene encoding a functional respiratory chain enzyme, it might be expected that coxl sequence data would 
show fewer between-species differences, and this might compromise discrimination between closely related species. For this study, the efficacy of three different published primer pairs for amplification of coxl in fish tissue samples was compared, namely FishF1, FishR1 (Ward et al., 2005); cichlidBS1(F), cichlidBS2(R) (Sparks, 2003); and tautog-BS1(F), tautog-BS2(R) (Orbacz and Gaffney, 2000). While all of the primer sets studied yielded PCR amplicons of approximately $650 \mathrm{bp}$ from fish tissue DNA extracts with varying success, the FishF1, FishR1 recently reported by Ward et al. (2005) for DNA barcoding of Australian fishes gave the most consistent results across a range of species tested and are therefore recommended to other workers (the authors thank Dr Ward for a pre-publication copy of his paper which assisted this study). Future workers in this field are advised to consider some of the coxl DNA sequence data available in the public domain with caution, since some of the reported sequences may in fact be of genomic origin (Ward et al., 2005; Zhang and Hewitt 1996; Richly and Lester 2004), or of other mitochondrial origin. For all fish species tested in this study (including all commercially important Plectropomus, Epinephelus, Lethrinis, and Lutjanus examples), the coxl sequences generated using the FishF1, FishR1 primer set gave reproducible sequences for each species that allowed ready species discrimination.

\section{CONCLUSIONS}

We conclude that the DNA Barcode approach for fish identification appears valid and that while HVRI or coxl mtDNA sequence data both appear useful for this purpose, coxl should be used in future studies as the marker of choice since a large international database for fish identification is presently being constructed. The coxl amplification and sequencing method allows identification of planktonic larval fish and fish eggs through comparison to DNA from authenticated adult fish specimens, and therefore provides a major new advance for fisheries biologists, taxonomists and fisheries regulators.

\section{REFERENCES}

Aspden, W.J., G.G. Pegg, L. van Heerwerden, S.J. Newman, and W. Sinclair. - 2005. Population Genetics of Red Throat Emperor of Australian East and West Coasts and Norfolk Island Based on Mitochondrial DNA Sequence. The $7^{\text {th }}$ Indo Pacific Fish Conference, Taipei, Taiwan. Abstract S1-07: p. 15.

Bay, L.K., J.H. Choat, L. van Heerwerden and D.R. Robertson. 2004. High genetic diversities and complex genetic structure in an Indo-pacific tropical fish species (Chlorurus sordidus): evidence of an unstable evolutionary past? Mar. Biol., 144: 757-767.

Hebert, P.D.N., A. Cywinska, S.L. Ball and J.R. de Waard. - 2003. Biological identifications through DNA barcodes. Proc. R. Soc. Lond. B., 270: 313-322.

Kumar S., K. Tamura, and M. Nei. - 2004. MEGA3: Integrated Software for Molecular Evolutionary Genetics Analysis and Sequence Alignment. Brief. Bioinform., 5: 150-163.

Leis, J.M. and B.M Carson-Ewart (eds.) - 2004. The larvae of IndoPacific coastal fishes. 2nd edition, Leiden; Boston: Brill.

Orbacz, E.A and P.M. Gaffney. - 2000. Genetic structure of tautog (Tautoga onitis) populations assayed by RFLP and DGGE analysis of mitochondrial and nuclear genes. Fish. Bull., 98: 336-344.

Richly, E. and D. Leister. - 2004. NUMTs in sequenced eukaryotic genomes. Mol. Biol. Evol., 21: 1081-1084.

Sambrook, J., E.F. Fritch, and T. Maniatis. - 1989. Molecular Cloning : a Laboratory Manual, 2nd edition, Cold Spring Harbour Laboratory press, Cold Spring Harbour.

Sparks, J.S. - 2004. Molecular phylogeny and biogeography of the Malagasy and South Asian cichlids (Teleostei: Perciformes: Cichlidae). Mol. Phylogenet. Evol., 30: 599-614.

Steinke, D., M. Vences, W. Salzburger, and A. Meyer. - 2005. TaxI: a software tool for DNA barcoding using distance methods. Phil. Trans. R. Soc. B., 360: 1975-1980.

Ward, R.D., T.S. Zemlak, B.H. Innes, P.R. Last, and P.D. Hebert. 2005. DNA Barcoding of Australia's fish species. Phil. Trans. R. Soc. B., 360: 1847-1857.

Zhang, D-X. and G.M. Hewitt. - 1996. Nuclear integrations: challenges for mitochondrial DNA markers. Trends Ecol. Evol., 11: 247-251.

Received February 9, 2005. Accepted November 21, 2005.

Published online September 28, 2006. 